O Open Access Full Text Article

ORIGINAL RESEARCH

\title{
A survey exploring knowledge and beliefs about electronic cigarettes between health care providers and the general population in Egypt
}

This article was published in the following Dove Press journal:

International Journal of Chronic Obstructive Pulmonary Disease

\author{
Ibrahim Dwedar' \\ Dina Ruby' \\ Aya Mostafa ${ }^{2}$ \\ 'Department of Chest, Faculty of \\ Medicine, Ain Shams University, Cairo, \\ Egypt; ${ }^{2}$ Department of Community, \\ Environmental and Occupational \\ Medicine, Faculty of Medicine, Ain Shams \\ University, Cairo, Egypt
}

Background: Electronic cigarettes are increasing in popularity, and they are easily accessible in a variety of locations. Despite increasing its popularity, little is known about its overall health effects. Physicians have rated the most trustful source of information about it and play also a role in disseminating information about it. Thus, this study identified the difference in knowledge and beliefs about electronic cigarettes between health care providers and the general population in Egypt.

Methods: A cross-sectional study using the self-administered questionnaire in the Arabic language was conducted between December 2018 and March 2019 in the Chest Department in Ain Shams University Hospital in Egypt. Study population $(\mathrm{n}=610)$ was divided into health care providers $(n=260)$ and general population $(n=350)$.

Result: A total of 593 respondents participated in this study and returned filled questionnaire with total response rate $=97.2 \%$, only $8.8 \%$ of all participates were smokers, none of the study population reported using electronic cigarettes, despite that, $79.3 \%$ of the participants have heard of electronic cigarettes, media advertisements were the main source of getting to know it and there was a statistically significant difference between both groups regarding most beliefs and attitudes toward electronic cigarettes.

Conclusion: There was high awareness about electronic cigarettes in Egypt and more negative attitude about it among health care providers than the general population, but still educational programs and guidelines for health care providers are needed to raise more the awareness which will aid in counseling general population appropriately.

Keywords: Egypt, electronic cigarettes, general population, health care providers, knowledge

\section{Introduction}

Increasing the use of tobacco imposes a great fear on public health as it has been linked to significant increases in coronary heart diseases, strokes and lung cancers. ${ }^{1}$ Tobacco is one of the major preventable causes of death in the world today and its usage kills up a lot of people ${ }^{2}$ and this is expected to occur in the developing countries. $^{3}$ There were various kinds of cigarettes (flavored, unfiltered, filtered, manufactured), pipes and cigars. ${ }^{4}$

Egypt is considered one of the highest countries in the use of tobacco in the Arab region. ${ }^{5}$ According to the WHO report, 22\% of Egyptian populations are current and former smokers, of which $43 \%$ male and about $1 \%$ female. ${ }^{6}$ Egypt has made great achievement in controlling tobacco use and reducing its harmful effects.
Faculty of Medicine, Ain Shams University, II Abbas El Akkad, The First Zone, Cairo II765, Egypt

Tel +20201102084652

Email drdina.ruby@med.asu.edu.eg 
Laws have banned indoor smoking in public places, ${ }^{7}$ moreover, no selling tobacco products to those $<18$ years old by law. ${ }^{8}$

Recently, there has been a growing trend toward a new type of device called electronic cigarettes (battery-powered devices that do not burn tobacco but aerosolize liquid and other preservatives for inhalation). ${ }^{9}$ The electronic cigarettes vaping is rapidly increasing worldwide ${ }^{10}$ and this may be due to commerce and media with its different types that convince people that the electronic cigarette is less harmful than a traditional cigarette and help with smoking cessation. In addition, electronic cigarette has various pleasant flavoring choices. All these causes encourage people to use electronic cigarette. ${ }^{11}$

The electronic cigarette is also common among smokers who cannot quit traditional cigarette, but are ready to switch to another tobacco type less harmful and its popularity had also increased among teens that have never used cigarettes. ${ }^{12}$ The long-term health effects of electronic cigarette are not yet known due to the short period since they had been known. ${ }^{13}$ And this creates a new challenge for public health. ${ }^{14}$ So, public health professionals are now divided into two groups, some consider it as a possible harm reduction tool for current smokers while others consider it the road to nicotine addiction and, in turn, other tobacco use. Therefore, WHO recommends limiting the sale of electronic cigarettes to the minimal, as well as its advertisement in the media. ${ }^{15}$ The Food and Drug Administration recently also announced at the beginning in 2018 that all e-cigarette advertisements and packaging need to affix a warning label ${ }^{16}$ stating the following: "WARNING: This product contains nicotine. Nicotine is an addictive chemical". 17

Although the literature on this topic is limited, it was found that $7-27 \%$ of smokers have discussed electronic cigarette with their physicians ${ }^{18}$ and a lot of the physicians lack the needed knowledge to give informed and valuable advice for patients and their families. ${ }^{19}$ Thus, this study aimed to assess the level of knowledge and beliefs of electronic cigarette among the health care providers and the general population and to compare the knowledge and the beliefs between them about the electronic cigarette.

\section{Materials and methods Study design}

The cross-sectional study was carried out from December 2018 to March 2019 in the Chest Department in Ain Shams University Hospital in Cairo, Egypt. Verbal informed consent was acceptable and approved by the Ethical Review Committee of the Faculty of Medicine, Ain Shams University.

\section{Study sample}

In this study, we targeted a convenience sample from two groups: the first group involved health care providers, who were either physicians or nurses working at the Chest Department in Ain Shams University Hospital; and the second group involved general population who were selected from among the visitors or workers in the same participating center who were 18 years or older and can read and write. The targeted sample size in each group was calculated; ${ }^{20}$ a total of 593 respondents participated in this study and returned filled questionnaires (of a total 610 targeted sample); 252 health care providers (of 260 targeted sample) and 341 general population (of 350 targeted sample).

Potential participants from both target groups provided verbal informed consent to share in this study after informing them about the aim of the study and that their sharing was not obligatory at all and they were given time to ask any inquiries if necessary.

Survey questionnaires were self-administered and distributed by the research team who was divided into three groups, researcher distributed a questionnaire to health care providers and other researcher distributed a questionnaire to the general population away from the first researcher until the target sample size was achieved and then data were analyzed by the third researcher by coding as a blind technique to avoid any bias.

\section{Study tool}

A self-administered questionnaire was adapted from previous relevant literature. ${ }^{21-23}$ The questionnaire was in English then translated into Arabic language and backtranslated into English for validation. A pilot test included 25 subjects (10 of health care provider and 15 of general populations) to test accuracy and the language of the questionnaire. Pilot test results were not included and no correction was conducted in the wording of the questionnaire after it. The final questionnaire consisted of three sections: Section I included data regarding participants' personal characteristics such as age (in years), gender and level of education, participants smoking status and type of tobacco used (cigarettes, water pipe, cigar, electronic cigarettes), and the duration of being a health care provider (for health care provider only: less than or equal 
5 years, $6-10$ years, $11-15$ years and more than 15 years); Section II included knowledge about electronic cigarettes included whether participants have ever heard of electronic cigarettes; those who have not ever heard of electronic cigarettes were asked to end the questionnaire at this stage and participants who have heard of electronic cigarettes were further asked how did they first learn about electronic cigarettes. Participants self-evaluated how much they knew about electronic cigarettes, and reported approximately what percentage of their friends (or patients if they were health care providers) were electronic cigarette users. Then, participants completed Section III, which included: beliefs and attitudes toward electronic cigarettes (all answers ranges from strongly agree to strongly disagree on a 5-point Likert scale) by asking them whether they thought electronic cigarettes: are safe, aid for smoking cessation, encourage smoking initiation and continuation, may cause long-term health effects, are a public health concern, should be avoided in public areas, can lower cancer risk than traditional cigarettes and whether they recommend the use of electronic cigarettes.

\section{Statistical analysis}

A continuous variable was presented as mean and standard deviation. Comparisons between means were done using the independant samples $t$-test for independent samples. Categorical data were presented as number and percentages. Comparison between proportions was done using the chi-square test. Data were statistically significant when $p$-values $=0.05$ or less. Data were analyzed by SPSS version 20 .

\section{Results}

\section{The studied sample}

A total of 593 respondents participated in this study and returned filled questionnaires (of a total 610 targeted sample, total response rate $=97.2 \%$ ); 252 health care providers (of 260 targeted sample, response rate among health care providers $=96.9 \%$ ) and 341 general population (of 350 targeted sample, response rate among health care providers $=97.4 \%$ ).

Participants' age ranged from 18 to 64 years with a mean age of $30.6 \pm 10.3$ years. Health care provider participants $(33.9 \pm 8.8)$ were older than the general population participants $(28.1 \pm 10.7)$ and this difference was statistically significant $\mathrm{t}=7.071, p<0.001$.Most participants were female $(63.2 \%)$, however there were significantly more female participants in the health care provider group (74.2\%) compared to the general population group (55.1\%), $p<0.001$.The highest educational level reported by participants was a master's degree in health care provider and a bachelor's degree in the general population. The majority of health care providers $(56.0 \%)$ reported receiving a bachelor's degree while the majority (63.9\%) of the general population reported receiving general secondary education. Only $8.8 \%$ of all participants were smokers. All smokers reported only cigarette smoking, none of the studied population reported using electronic cigarettes. Smoking was reported more in the general population group $(11.7 \%)$ compared to the health care provider group (2.4\%), $p<0.001$ in Table 1.

\section{Knowledge about electronic cigarettes}

Most participants have heard of electronic cigarettes $(n=470,79.3 \%)$; significantly more among the general population $(85.3 \%)$ than health care providers $(71.0 \%)$, $p<0.001$.Participants who have not ever heard about electronic cigarettes $(\mathrm{n}=123,20.7 \%)$ discontinued the questionnaire at this stage in Table 2.

Media advertisements were the main source of getting to know electronic cigarettes for the first time among participants $(50.4 \%)$. Also, a considerable proportion of participants first heard about electronic cigarettes from their friends or clients (33.2\%) in Table 2.

The majority of both health care providers and the general population considered they knew a little about electronic cigarettes $(65.4 \%$ and $65.3 \%$, respectively). However, significantly more general population knew nothing at all about electronic cigarettes compared to health care providers (16.2\% versus $8.9 \%$, respectively), $p=0.001$ in Table 2 .

Almost all participants $(91.2 \%)$ reported that approximately only a quarter or less of their friends or patients were electronic cigarette users in Table 2.

\section{Beliefs and attitudes toward electronic cigarettes}

There were significant statistical difference in most of the beliefs and attitudes between participants,most of the health care providers believe that electronic cigarette was unsafe, did not help in smoking cessation, and encouraged smoking continuation and contain chemicals that may cause long-term health effects and should be regulated in public places and did not lower cancer risk, but both 
Table I Characteristics of the studied sample

\begin{tabular}{|c|c|c|c|c|c|c|c|c|}
\hline & & \multirow{2}{*}{$\begin{array}{l}\text { Total N=593 } \\
\text { No (\%) }\end{array}$} & \multicolumn{2}{|c|}{$\begin{array}{l}\text { Health care providers } \\
N=252\end{array}$} & \multicolumn{2}{|c|}{$\begin{array}{l}\text { General population } \\
\mathrm{N}=34 \text { I }\end{array}$} & \multirow[t]{2}{*}{ Chi-square } & \multirow[t]{2}{*}{$p$-value } \\
\hline & & & No & $\%$ & No & $\%$ & & \\
\hline Gender & $\begin{array}{l}\text { Female } \\
\text { Male }\end{array}$ & $\begin{array}{l}375(63.2) \\
218(36.8)\end{array}$ & $\begin{array}{l}187 \\
65\end{array}$ & $\begin{array}{l}74.2 \\
25.8\end{array}$ & $\begin{array}{l}188 \\
153\end{array}$ & $\begin{array}{l}55.1 \\
44.9\end{array}$ & 22.679 & $<0.001$ \\
\hline Age categories & $\begin{array}{l}18- \\
30- \\
40- \\
50+\end{array}$ & $\begin{array}{l}347(58.5) \\
132(22.3) \\
71(12.0) \\
43(7.3)\end{array}$ & $\begin{array}{l}105 \\
90 \\
34 \\
23\end{array}$ & $\begin{array}{l}41.7 \\
35.7 \\
13.5 \\
9.1\end{array}$ & $\begin{array}{l}242 \\
42 \\
37 \\
20\end{array}$ & $\begin{array}{l}71.0 \\
12.3 \\
10.9 \\
5.9\end{array}$ & $59.87 \mid$ & $<0.001$ \\
\hline Education & $\begin{array}{l}\text { General secondary } \\
\text { Technical education } \\
\text { Post-secondary diploma } \\
\text { Bachelor's degree } \\
\text { Master's degree }\end{array}$ & $\begin{array}{l}218(36.8) \\
44(7.4) \\
68(11.5) \\
211(35.6) \\
52(8.8)\end{array}$ & $\begin{array}{l}0 \\
0 \\
59 \\
141 \\
52\end{array}$ & $\begin{array}{l}0 \\
0 \\
23.4 \\
56.0 \\
20.6\end{array}$ & $\begin{array}{l}218 \\
44 \\
9 \\
70 \\
0\end{array}$ & $\begin{array}{l}63.9 \\
12.9 \\
2.6 \\
20.5 \\
0\end{array}$ & 369.624 & $<0.001$ \\
\hline Smoking status & $\begin{array}{l}\text { Smokers } \\
\text { Ex-smokers } \\
\text { Non smoker }\end{array}$ & $\begin{array}{l}46(7.8) \\
37(6.2) \\
510(86.0)\end{array}$ & $\begin{array}{l}6 \\
15 \\
231\end{array}$ & $\begin{array}{l}2.4 \\
6.0 \\
91.7\end{array}$ & $\begin{array}{l}40 \\
22 \\
279\end{array}$ & $\begin{array}{l}11.7 \\
6.5 \\
81.8\end{array}$ & $|8.02|$ & $<0.001$ \\
\hline
\end{tabular}

(68.1\%) health care providers and $(60.8 \%)$ general population agreed that that electronic cigarette was public health concern in Table 3.

Only $6.9 \%$ of health care providers and $10.8 \%$ of the general population recommended e-cigarette to others. The difference between participant was statistically insignificant (chi-square test $=1.972, p=0.188$ ).

\section{Discussion}

The electronic cigarettes' popularity nowadays is rising globally, although data available on its safety and efficacy are limited. ${ }^{24}$ And the rate of its awareness and usage are not known in some countries. ${ }^{25}$ But some studies showed a significant rise in its awareness over recent years. ${ }^{26}$

Physicians have rated the most trusted sources of information for smokers; thus, they play the main role in disseminating information to the general population. ${ }^{27}$ Therefore, this study was conducted to compare the knowledge and beliefs about electronic cigarettes between the health care providers either physicians or nurses who deliver education and guidance about electronic cigarettes and the general population who use it in Egypt.

In the present study, most participants $63.2 \%$ were female, the majority of health care providers reported receiving a bachelor's degree and most of the health care provider participants $47.2 \%$ have been working in the health care since $<5$ years, which means that they were junior staff and this was the target group who deal with general population and spread information about electronic cigarettes while the majority of the general population reported receiving general secondary education.

Most of participants (79.3\%)in this study have heard of electronic cigarette, more among the general population $(\mathrm{n}=292,85.3 \%)$ than health care providers $(\mathrm{n}=179,71 \%)$ and this can be explained that the majority of health care providers were female who may have less knowledge and interest in the matter as 70 of 73 health care providers who did not hear about e-cigarette and did not continue the questionnaire were female and three of them only were male and this point needs to have focus on it as physician regardless the gender should know enough knowledge about e-cigarette to deliver information about it to the general population.

Abo-Elkheir and $\mathrm{Sobh}^{28}$ studied the prevalence of knowledge about electronic cigarettes and its use among the Egyptian population in 2016 and it was found that the awareness rate was $57.5 \%$ and $75.4 \%$ of their participants were male but there was still an agreement with the present study with higher awareness rate in the present study although the majority were female. But awareness rate about electronic cigarettes in this study was lower than the study carried out in Saudi Arabia by Karbouji et al ${ }^{29}$ who found that the awareness about electronic cigarettes was $93.6 \%$ and the majority of their participants were male and lower than the study carried out in Malaysia in which $95 \%$ of their studied population was aware of $\mathrm{it}^{30}$ and the 
Table 2 Knowledge about electronic cigarettes among study participants

\begin{tabular}{|c|c|c|c|c|c|c|c|c|}
\hline & & \multirow{2}{*}{$\begin{array}{l}\text { Total } \mathbf{N}=\mathbf{5 9 3} \\
\text { No (\%) }\end{array}$} & \multicolumn{2}{|c|}{$\begin{array}{l}\text { Health } \\
\text { care } \\
\text { providers } \\
\mathrm{N}=252\end{array}$} & \multicolumn{2}{|c|}{$\begin{array}{l}\text { General } \\
\text { population } \\
\mathrm{N}=34 \text { I }\end{array}$} & \multirow[t]{2}{*}{ Chi-square } & \multirow[t]{2}{*}{$p$-value } \\
\hline & & & No & $\%$ & No & $\%$ & & \\
\hline \multirow{2}{*}{\multicolumn{2}{|c|}{ Have you ever heard of electronic cigarettes, yes }} & $470(79.3 \%)$ & 179 & 71.0 & 291 & 85.3 & 18.039 & $<0.001$ \\
\hline & & $N=470$ & \multicolumn{2}{|c|}{$N=179$} & \multicolumn{2}{|c|}{$\mathbf{N}=291$} & & \\
\hline $\begin{array}{l}\text { How did you first learn about electronic } \\
\text { cigarettes }\end{array}$ & $\begin{array}{l}\text { Media } \\
\text { advertisement } \\
\text { Newspapers } \\
\text { Roadside } \\
\text { poster } \\
\text { Patients } \\
\text { Friends or } \\
\text { clients } \\
\text { Professional } \\
\text { source } \\
\text { Other }\end{array}$ & $\begin{array}{l}237(50.4) \\
11(2.3) \\
5(1.1) \\
15(3.2) \\
156(33.2) \\
14(3.0) \\
32(6.8)\end{array}$ & $\begin{array}{l}83 \\
4 \\
0 \\
10 \\
50 \\
12 \\
20\end{array}$ & $\begin{array}{l}46.4 \\
2.2 \\
0.0 \\
5.6 \\
27.9 \\
6.7 \\
11.2\end{array}$ & $\begin{array}{l}154 \\
7 \\
5 \\
5 \\
106 \\
2 \\
12\end{array}$ & $\begin{array}{l}52.9 \\
2.4 \\
1.7 \\
1.7 \\
36.4 \\
0.7 \\
4.1\end{array}$ & 33.196 & $<0.001$ \\
\hline $\begin{array}{l}\text { How much do you know about electronic } \\
\text { cigarettes }\end{array}$ & $\begin{array}{l}\text { Nothing at all } \\
\text { A little } \\
\text { A moderate } \\
\text { amount } \\
\text { Quite a lot }\end{array}$ & $\begin{array}{l}63(13.4) \\
307(65.3) \\
90(19.1) \\
10(2.1)\end{array}$ & $\begin{array}{l}18 \\
117 \\
46 \\
0\end{array}$ & $\begin{array}{l}8.9 \\
65.4 \\
25.7 \\
\\
0.0\end{array}$ & $\begin{array}{l}47 \\
190 \\
44 \\
10\end{array}$ & $\begin{array}{l}16.2 \\
65.3 \\
15.1 \\
3.4\end{array}$ & 16.929 & 0.001 \\
\hline $\begin{array}{l}\text { About what percentage of your friends or your } \\
\text { patients use electronic cigarettes }\end{array}$ & $\begin{array}{l}0-25 \% \\
26-50 \% \\
51-75 \% \\
76-100 \%\end{array}$ & $\begin{array}{l}429(91.2) \\
14(3.0) \\
15(3.2) \\
12(2.6)\end{array}$ & $\begin{array}{l}177 \\
0 \\
0 \\
2\end{array}$ & $\begin{array}{l}98.9 \\
0.0 \\
0.0 \\
1.1\end{array}$ & $\begin{array}{l}252 \\
14 \\
15 \\
10\end{array}$ & $\begin{array}{l}86.6 \\
4.8 \\
5.2 \\
3.4\end{array}$ & 21.431 & $<0.001$ \\
\hline
\end{tabular}

majority of their participants were female and the possible explanation for the higher awareness rate in both studies that the participants were using e-cigarettes $(68.9 \%$ and $13.8 \%$, respectively).

Among our studied groups, only $8.8 \%$ of all participants were smokers to traditional cigarettes and none of them were using e-cigarettes which were similar to the study done in Egypt 2016, ${ }^{28}$ nobody of them reported use of e-cigarettes and up to our knowledge there was no study that had assessed the prevalence of electronic cigarette's user in Egypt, although in the present study we asked participants approximately about what percentage of their friends (or patients if they were health care providers) were electronic cigarette users and almost all participants $(91.2 \%)$ reported that approximately only a quarter or less of their friends or patients were electronic cigarette users but we still need further studies to assess the actual prevalence of electronic cigarettes user in Egypt. Zhu et $\mathrm{al}^{31}$ carried their survey of the US population and the sample size was 10,041 and they found that $75.4 \%$ heard about ecigarette, $8.08 \%$ of them had tried it and $1.44 \%$ was already using it and this revealed high awareness rate in Egypt although we used a smaller sample size and none of the participants were e-cigarette user.

The main source about electronic cigarettes in this study was media advertisement $(50.4 \%)$ while in the earlier study, which was done in Egypt, ${ }^{28} 74.8 \%$ of them had heard about it from multiple sources.

And in the previous studies, ${ }^{32}$ the Internet, friends or personal contacts, and advertisements were the most common sources mentioned. Martínez-Sánchez et al ${ }^{33}$ stated that most participants had learned about it through traditional media. While Zhu et al. ${ }^{31}$ found that most of the elderly with low education heard about electronic cigarettes from television while the young people with high education heard about it from the Internet. Meanwhile, other studies found that information on electronic cigarette spread widely through social media. ${ }^{34}$ 


\begin{tabular}{|c|c|c|c|c|c|}
\hline \multicolumn{2}{|l|}{$\begin{array}{l}\frac{0}{2} \\
\frac{\pi}{10} \\
\frac{1}{2}\end{array}$} & $\begin{array}{l}\overline{8} \text { m } \overline{8} \\
\text { Oें } \\
\text { v }\end{array}$ & $\frac{a}{0}$ & $\begin{array}{l}\overline{8} \\
\text { v }\end{array}$ & 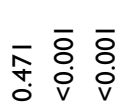 \\
\hline \multicolumn{2}{|l|}{ 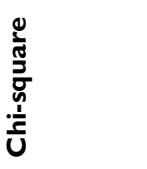 } & 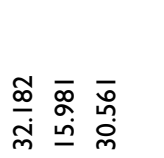 & 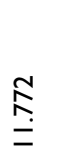 & $\begin{array}{l}\bar{\sigma} \\
\dot{m} \\
\dot{q}\end{array}$ & $\begin{array}{l}\text { 우 } \bar{T} \\
\text { ஸैं } \\
\text { m̃ } \\
\text { 워 }\end{array}$ \\
\hline \multirow{5}{*}{ 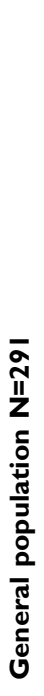 } & 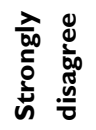 & $\stackrel{\forall}{\dot{m}} \stackrel{\ddot{m}}{\underline{i}}$ & $\stackrel{亠}{i}$ & $\underline{-}$ & ^ \\
\hline & 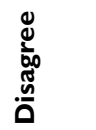 & 일 芦 & $\stackrel{a}{a}$ & $\underset{\infty}{\sim}$ & 追 우 \\
\hline & $\begin{array}{l}\overline{0} \\
\overline{\frac{0}{2}} \\
\mathbf{Z} \\
\mathbf{Z}\end{array}$ & ભm & $\stackrel{\infty}{\sim}$ & $\overline{\text { Dे }}$ & 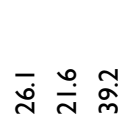 \\
\hline & $\frac{8}{\frac{0}{0.0}}$ & $\stackrel{ }{\simeq} \stackrel{ }{\simeq}$ & 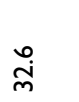 & 웅 & ò \\
\hline & 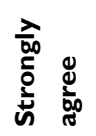 & $\bar{\forall}$ i $\stackrel{\circ}{\circ}$ & $\stackrel{1}{x}$ & $\stackrel{a}{\underline{a}}$ & 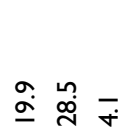 \\
\hline \multirow{5}{*}{ 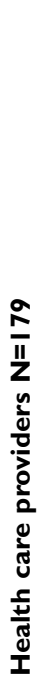 } & 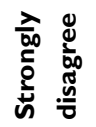 & m & $\underset{\sim}{\mathscr{r}}$ & $\stackrel{n}{\stackrel{n}{*}}$ & 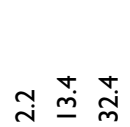 \\
\hline & 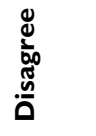 & 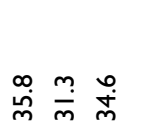 & $\stackrel{\circ}{0}$ & $\stackrel{\sigma}{m}$ & 으 늠 $\stackrel{n}{m}$ \\
\hline & $\begin{array}{l}\bar{T} \\
\text { 苞 } \\
\text { Z }\end{array}$ & 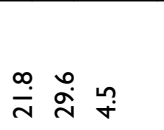 & $\begin{array}{l}\stackrel{0}{0} \\
\underline{0}\end{array}$ & $\hat{\jmath}$ & $\stackrel{\circ}{\sim} \underset{\sim}{ } \stackrel{\infty}{\dot{\varphi}}$ \\
\hline & 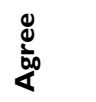 & $\stackrel{+}{=} \stackrel{+}{\underline{m}} \overline{\dot{d}}$ & $\overline{\bar{\sigma}}$ & $\stackrel{\sim}{g}$ & 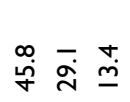 \\
\hline & 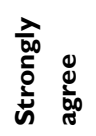 & 웅 웅 & $\frac{\hat{N}}{N}$ & $\stackrel{\infty}{\stackrel{\infty}{m}}$ & 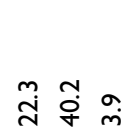 \\
\hline \multicolumn{2}{|l|}{ 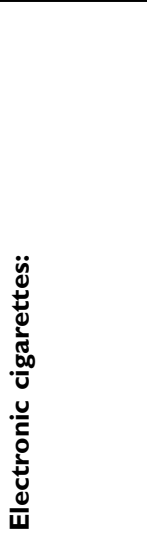 } & 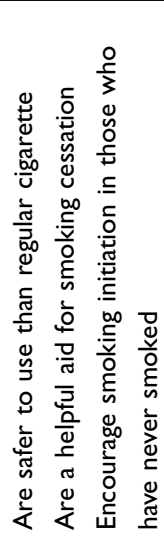 & 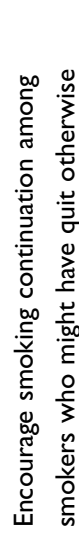 & 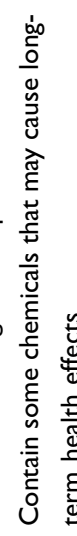 & 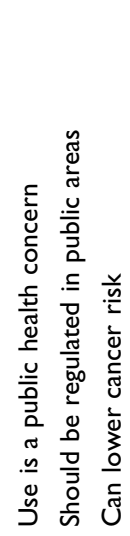 \\
\hline
\end{tabular}

In the study done in Egypt $2016,{ }^{28} 68.1 \%$ believe that electronic cigarette was unsafe than traditional cigarettes but in this study only $46 \%$ of the general population believe that e-cigarette was unsafe and this can be explained due to marketing and media that play a major role in making people believe that e-cigarette is less harmful than traditional cigarettes. ${ }^{11}$

But our results were still better than Karbouji et al ${ }^{29}$ who found that only $10.7 \%$ only believe that they are as dangerous as or more dangerous than cigarettes. In contrast, $67.1 \%$ of health care providers believe that e-cigarette was unsafe and this was a good point as physicians were the major source to balance the widely available information about ecigarettes from different sources which may not be evidence-based or scientifically accurate.

$57 \%$ of our health care providers and $48.8 \%$ of general population who heard about e-cigarette disagree that it helps in smoking cessation that was nearly similar to the study done in Egypt $2016^{28}$ as $58.4 \%$ disagree that electronic cigarettes aid in smoking cessation, but different from Karbouji et $\mathrm{al}^{29}$ in which only $13.4 \%$ disagree that electronic cigarettes help in smoking cessation and this may be due to $68.9 \%$ were vape users, $5.9 \%$ used to smoke vape in the past, so they had some biases toward e-cigarette, while in this study and study done in Egypt $2016,{ }^{28}$ none of the participants were e-cigarette user.

Both Abo-Elkheir and Sobh, ${ }^{28}$ and Karbouji et $\mathrm{al}^{29}$ discussed knowledge about electronic cigarettes in the general population only in the Arab region in Egypt and Saudi Arabia while in this study, we compared the beliefs and attitudes about electronic cigarettes between the general population and health care providers.

\section{Conclusion}

There was high awareness about electronic cigarettes in Egypt and more negative attitude about it among health care providers than the general population, but still educational programs and guidelines for health care providers are needed to raise more the awareness which will aid in counseling general population appropriately.

\section{Abbreviations}

E-cigarette, electronic cigarette; WHO, World Health Organization.

\section{Acknowledgment}

Professor Moustafa El Housinie helped in the study analysis. 


\section{Disclosure}

The authors report no financial interest or other conflicts of interest in this work.

\section{References}

1. Mackenbach JP, Damhuis RA, Been JV. The effects of smoking on health: growth of knowledge reveals even grimmer picture (article in Dutch-English). Ned Tijdschr Geneeskd. 2017;160:869.

2. Mathers C, Loncar D. Projections of global mortality and burden of disease from 2002 to 2030. PLoS Med. 2006;443:442. doi:10.1371/ journal.pmed.0030442

3. Jha $\mathrm{P}$,Chaloupka FJ, Moore $\mathrm{J}$ et al. Tobacco addiction. In: Jamison D, editor. Disease Control Priorities in Developing Countries, 2nd ed. Washington (DC): The World Bank; 2006:869-888.

4. World Health Organization. WHO report on the global tobacco epidemic. The MPOWER package

5. Hanafy K, Saleh A, Elmallah M, Omar H, Bakr D, Chaloupka F. The Economics of Tobacco and Tobacco Taxation in Egypt. Paris, France: International Union against Tuberculosis and Lung Disease; 2010.

6. World Health Organization (WHO). Global Report on Trends in Prevalence of Tobacco Smoking 2015. Geneva: World Health Organization; 2015.

7. Radwan N, Loffredo A, Aziz R, AbdelAziz N, Labib N. Implementation, barriers and challenges of smoke-free policies in hospitals in Egypt. BMC Res Notes. 2012;5:568. doi:10.1186/1756-0500-5-568

8. Executive Bylaw of Legislation 52 for 1981; concerning the prevention of adverse effects of tobacco; Egypt. Available from: http://www.tobaccocon trollaws.org/legislation/country/Egypt/laws. Accessed January 13, 2016.

9. Rigotti N. Strategies to help a smoker who is struggling to quit. $J \mathrm{Am}$ Med Assoc. 2012;308:1573-1580. doi:10.1001/jama.2012.13043

10. Michael F Marlboro maker to launch new electronic cigarette. 2013. Available from: https://www.huffingtonpost.com/2013/06/11/marlboroelectronic-cigarette_n_3420938.htm. Accessed August 05, 2019.

11. Ayers JW, Leas EC, Allem JP, et al. Why do people use electronic nicotine delivery systems (electronic cigarettes)?A content analysis of Twitter, 2012-2015. PLoS One. 2017;12:1772. doi:10.1371/journal.pone. 0170702

12. Besaratinia A, Tommasi S. An opportune and unique research to evaluate the public health impact of electronic cigarettes. Cancer Causes Control. 2017;10:1167-1171. doi:10.1007/s10552-017-0952-5

13. Breland B, Spindle T, Weaver M, Eissenberg T. Science and electronic cigarettes: current data, future needs. $J$ Addict Med. 2014;8:223233. doi:10.1097/ADM.0000000000000049

14. Schraufnagel E, Blasi F, Drummond B, et al. Forum of international respiratory societies. Electronic cigarettes. A position statement of the forum of international respiratory societies. Am J Respir Crit Care Med. 2014;190:611-618. doi:10.1164/rccm.201407-1198PP

15. World Health Organization (WHO). WHO framework convention on tobacco control. Electronic nicotine delivery systems Report by WHO, FCTC/COP/6/10. Moscow, Russia, July 21, 2014.

16. Jacob AR, MN S, Casey H, Allison J, Jennifer CR, Erin LS. The role of knowledge and risk beliefs in adolescent e-cigarette use: a pilot study. Int J Environ Res Public Health. 2018;15(4):830. doi:10.3390/ ijerph15061188

17. Food and Drug Administration. Deeming tobacco products to be subject to the federal food, drug, and cosmetic act, as amended by the family smoking prevention and tobacco control act; restrictions on the sale and distribution of tobacco products and required warning statements for tobacco products. Fed Regist. 2016;81:28973-29106.
18. Wackowski A, Manderski B, Delnevo D. Smokers' sources of ecigarette awareness and risk information. Prev Med Reports. 2015;906-910. doi:10.1016/j.pmedr.2015.10.006

19. El-Shahawy O, Brown R, Elston Lafata J. Primary care physicians' beliefs and practices regarding e-cigarette use by patients who smoke: a qualitative assessment. Int J Environ Res Public Health. 2016;13:445. doi:10.3390/ijerph13121252

20. Machin D, Campbell M, Tan BT, Tan SH. Sample Size Tables for Clinical Studies. 3rd ed. Chicester: Wiley-Blackwell; 2009.

21. Quinta M, Olabode A, Darleesa D. Nurses' knowledge, beliefs, attitudes, and practices regarding electronic cigarettes: a cross- sectional study. Tob Prev Cess. 2017;3:125.

22. Geletko K, Myers K, Brownstein N, et al. Medical residents' and practicing physicians' e-cigarette knowledge and patient screening activities: do they differ? Health Serv Res Manag Epidemiol. 2016;3:23.

23. Kandra K, Ranney L, Lee JG, Goldstein A. Physicians' attitudes and use of e-cigarettes as cessation devices, North Carolina. PLoS One. 2013;9:103462. doi:10.1371/journal.pone.0103462

24. Iqbal N, Khan Z, Anwar S, et al. Electronic cigarettes use and perception amongst medical students: a cross sectional survey from Sindh, Pakistan. BMC Res Notes. 2018;11:18. doi:10.1186/s13104018-3303-z

25. Grana A, Popova L, Ling M. A longitudinal analysis of electronic cigarette use and smoking cessation. JAMA Intern Med. 2014;174:812-813. doi:10.1001/jamainternmed.2014.187

26. Britton J, Bogdanovica I. Electronic Cigarettes; a Report Commissioned by Public Health England. Wellington House: Public Health England, 2014.

27. Singh B, Hrywna M, Wackowski OA, Delnevo CD, Jane Lewis M, Steinberg MB. Knowledge, recommendation, and beliefs of e-cigarettes among physicians involved in tobacco cessation: a qualitative study. Prev Med Rep. 2017;8:25-29. doi:10.1016/j. pmedr.2017.07.012

28. Abo-Elkheir O, Sobh E. Knowledge about electronic cigarettes and its perception: a community survey, Egypt. Respir Res. 2016;17:58. doi:10.1186/s12931-016-0365-0

29. Karbouji M, Abduldaem A, Allogmani A, Alharbi A, Alnozha O, AlZalabani A. Awareness and attitude toward smoking e-cigarettes (Vape) among smokers in Saudi Arabia 2017. Egypt J Hosp Med. 2018;70:1346-1351. doi:10.12816/0044646

30. Goha Y, Dujailia J, Blebilb A, Ahmed S. Awareness and use of electronic cigarettes: perceptions of health science programme students in Malaysia. Health Educ J. 2017;76:33-38.

31. Zhu S-H, Gamst A, Lee M, Cummins S, Yin L, Zoref L. The use and perception of electronic cigarettes and snus among the U.S. population. PLoS One. 2013;8:79332. doi:10.1371/journal.pone.0079332

32. Dawkins L, Turner J, Roberts A, Soar K. 'Vaping' profiles and preferences: a non line survey of electronic cigarette users. Addiction. 2013;108:1115-1125. doi:10.1111/add.2013.108.issue-6

33. Martínez-Sánchez M, Fu M, Ballbè M, Martin SJ, Saltó E, Fernández E. Knowledge of electronic cigarettes and their perceived harmfulnessamong the adult population in Barcelona (Spain). Gac Sanit. 2015;29:296-299. doi:10.1016/j.gaceta.2015.01.003

34. Emery L, Vera L, Huang J, Szczypka G. Wanna know about vaping? Patterns of message exposure, seeking and sharing information about e-cigarettes across media platforms. Tob Control. 2014;23:17-25. doi:10.1136/tobaccocontrol-2014-051648 


\section{Publish your work in this journal}

The International Journal of COPD is an international, peer-reviewed journal of therapeutics and pharmacology focusing on concise rapid reporting of clinical studies and reviews in COPD. Special focus is given to the pathophysiological processes underlying the disease, intervention programs, patient focused education, and self management protocols. This journal is indexed on PubMed Central, MedLine and CAS. The manuscript management system is completely online and includes a very quick and fair peer-review system, which is all easy to use. Visit http://www.dovepress.com/testimonials.php to read real quotes from published authors. 